\title{
Assignment of the group A rotavirus NSP4 gene into genotypes using a hemi-nested multiplex PCR assay: a rapid and reproducible assay for strain surveillance studies
}

\section{Correspondence \\ Krisztián Bányai \\ bkrota@hotmail.com}

Received 16 July 2008

Accepted 12 November 2008

\author{
Krisztián Bányai, ${ }^{1,2}$ Ágnes Bogdán, ${ }^{1}$ György Szücs, ${ }^{1}$ Serenella Arista, ${ }^{3}$ \\ Simona De Grazia, ${ }^{3}$ Gagandeep Kang, ${ }^{4}$ Indrani Banerjee, ${ }^{4}$ \\ Miren Iturriza-Gómara, ${ }^{5}$ Canio Buonavoglia ${ }^{6}$ and Vito Martella ${ }^{6}$ \\ ${ }^{1}$ Regional Laboratory of Virology, Baranya County Institute of State Public Health Service, Pécs, \\ Hungary \\ ${ }^{2}$ Veterinary Medical Research Institute, Hungarian Academy of Sciences, Budapest, Hungary \\ ${ }^{3}$ Department of Hygiene and Microbiology, University of Palermo, Palermo, Italy \\ ${ }^{4}$ Department of Gastrointestinal Sciences, Christian Medical College and Hospital, Vellore, India \\ ${ }^{5}$ Enteric Virus Unit, Enteric, Respiratory and Neurological Virus Laboratory, Health Protection \\ Agency, London, UK \\ ${ }^{6}$ Department of Public Health and Zootecnic, Faculty of Veterinary Medicine, University of Bari, \\ Bari, Italy
}

\begin{abstract}
The rotavirus non-structural protein NSP4 has been implicated in a number of biological functions during the rotavirus cellular cycle and pathogenesis, and has been addressed as a target for vaccine development. The NSP4 gene has been classified into six genotypes (A-F). A seminested triplex PCR was developed for genotyping the major human NSP4 genotypes $(A-C)$, which are common in human rotavirus strains but are also shared among most mammalian rotavirus strains. A total of 192 previously characterized human strains representing numerous $G$ and P type specificities (such as G1P[8], G1P[4], G2P[4], G3P[3], G3P[8], G3P[9], G4P[6], G4P[8], G6P[4], G6P[9], G6P[14], G8P[10], G8P[14], G9P[8], G9P[11], G10P[11], G12P[6] and G12P[8]) were tested for NSP4 specificity by the collaborating laboratories. An additional 35 animal strains, including the reference laboratory strains SA11 (simian, G3P[2]), NCDV (bovine, G6P[1]), K9 and CU-1 (canine, G3P[3]), together with 31 field isolates (canine, G3P[3]; feline, G3P[9]; porcine, G2P[23], G3P[6], G4P[6], G5P[6], G5P[7], G5P[26], G5P[27], G9P[6] and G9P[7]) were also successfully NSP4-typed. Four human G3P[9] strains and one feline G3P[9] strain were found to possess an NSP4 A genotype, instead of NSP4 C, suggesting a reassortment event between heterologous strains. Routine NSP4 genotyping may help to determine the genomic constellation of rotaviruses of man and livestock, and identify interspecies transmission of heterologous strains.
\end{abstract}

\section{INTRODUCTION}

Group A rotaviruses (genus Rotavirus, family Reoviridae) cause severe acute dehydrating diarrhoea in young children and domestic animals (Estes \& Kapikian, 2006). They are classified based on antigenic and genetic differences in both structural and non-structural genes. The outer capsid antigens VP7 and VP4 define the G and P types, respectively. So far, at least $15 \mathrm{G}$ genotypes (G1-G15) and $27 \mathrm{P}$ genotypes $(\mathrm{P}[1]-\mathrm{P}[27])$ have been identified (Estes \& Kapikian, 2006; Khamrin et al., 2007; Martella et al., 2007; Steyer et al., 2007). The inner capsid protein VP6 has 
been classified into four antigenic subgroups (SGI, SGII, SGI+II and SG nonI-nonII) representing two major genogroups (GGI and GGII) (Estes \& Kapikian, 2006). A genotyping system has been proposed for the nonstructural rotaviral enterotoxin, NSP4. Six NSP4 genotypes (A-F) have been defined, based on sequence and phylogenetic analyses (Estes \& Kapikian, 2006). Three NSP4 genotypes (A-C) have been identified in human rotaviruses; these are also shared by most mammalian rotaviruses. Furthermore, the migration pattern of the 11 genomic RNA segments, called the electropherotype (Etype), allows group A rotaviruses to be classified into long, short and supershort E-types (Estes \& Kapikian, 2006).

A variety of RT-PCR-based genotyping assays have been developed since the early 1990s. These assays target primarily the VP7 and VP4 genes and, more recently, the NSP4 gene (Gouvea et al., 1990, 1994a, b; Gentsch et al., 1992; Das et al., 1994; Ray et al., 2003; Rodríguez-Díaz et al., 2008), although RT-PCR amplification combined with either RFLP analysis or nucleotide sequencing of various genes has also been adapted for strain characterization in various laboratories (Gouvea et al., 1993; Iizuka et al., 1993; Chang et al., 1996; Dubois et al., 1997; Hussein et al., 1997; Kudo et al., 2001; O'Halloran et al., 2002; DiStefano et al., 2005). A combination of typing methods based on a variety of genes provides a means of characterizing group A rotavirus strains of most host species and generates insight into the genetic diversity and ecology of these viruses.

A rapid and economically beneficial multiplex PCR assay for the rotaviral enterotoxin NSP4 is described in this paper. This method is based on the methodologies that are broadly utilized for P and G genotyping and thus represents a rapid and reliable screening tool that may readily supplement human and animal rotavirus strain surveillance activities.

\section{METHODS}

Collaborating laboratories. Four laboratories in three countries participated in the evaluation of the NSP4 typing assay described below. The Hungarian laboratory was the National Reference Laboratory for Viral Gastroenteritis. Two Italian laboratories, one located in Palermo, Sicily, at the Department of Hygiene and Microbiology, University of Palermo, and the other in Bari, Puglia, at the Faculty of Veterinary Medicine of Bari, participated. The Indian laboratory was located in Vellore, India, at the Department of Gastrointestinal Sciences, Christian Medical College and Hospital.

Samples. Stool specimens positive for rotaviruses and supernatants of cell cultures infected with laboratory strains were tested using this assay. All strains had previously been subjected to $G$ and $P$ typing using previously described methods and algorithms (Gouvea et al., 1990; Gentsch et al., 1992; Das et al., 1994; Bányai et al., 2003; Iturriza-Gómara et al., 2004). For a subset of samples, VP6 was subgrouped using SGI- and SGII-specific mAbs (clones 255/60 and 631/9; Greenberg et al., 1983) or genogrouped as described previously (Iturriza-Gómara et al., 2002), and the E-type of genomic RNA was determined by PAGE (Dolan et al., 1985). The reference rotavirus strains used to validate this assay are listed in Table 1.
Typing primers. The external primers for first-round PCR, $151\left(5^{\prime}\right.$ GGCTTTWAAAAGTTCTGTTCCGAGAGAG-3', sense) and 152 (5' TAAGACCRTTCCYTCCATTAAC- $3^{\prime}$, antisense), were derived from nt 1-28 and 721-742, respectively, relative to strain WA (GenBank accession no. AF093199; Fig. 1). The genotype-specific primers for the second-round PCR were 235 (genotype B) (5'GACACATTACATTCTATWATTC-3'), 236 (genotype C) (5'CAACYATGAAGATYGCTCTT- $3^{\prime}$ ) and 237 (genotype A) (5'CCAAAAGAAGTGACTGCAGCRA-3'), derived from nt 96-117 (strain WA, GenBank accession no. AF093199, genotype B), nt 196-215 (strain AU1, GenBank accession no. D89873, genotype C) and nt 543-564 (strain KUN, GenBank accession no. D88829, genotype A), respectively. The oligonucleotides were designed by visual inspection of an alignment containing a selection of 75 NSP4 sequences (see supplementary Table S1 in JMM Online) of human and animal rotaviruses.

General protocol for the triplex RT-PCR assay. Briefly, viral RNA was extracted using SDS/proteinase $\mathrm{K}$ treatment followed by guanidine thiocyanate/silica treatment (Boom et al., 1990), or with commercial column-based extraction kits. The cDNA was constructed with random hexamers ( $2 \mu \mathrm{M}$ final concentration) or with the genespecific consensus primers 151 and 152 (400 nM final concentration). Typically, both first-round and second-round PCRs were carried out in a $50 \mu \mathrm{l}$ volume, containing $1 \times$ PCR buffer $[75 \mathrm{mM}$ Tris/HCl $(\mathrm{pH}$ 8.8), $20 \mathrm{mM}\left(\mathrm{NH}_{4}\right)_{2} \mathrm{SO}_{4}, 0.01 \%$ Tween $20,2 \mathrm{mM} \mathrm{MgCl}$ ], $200 \mu \mathrm{M}$ dNTP mix, the appropriate primer mixture (400 nm each) used, respectively, in the first and second round, 2.5 U Taq polymerase and 1-5 $\mu \mathrm{l} \mathrm{cDNA}$ or first-round PCR product (the latter was diluted $1: 100$ or $1: 200$ before addition to the second-round PCR mixture). In both rounds, PCR was carried out for 25 cycles of $94{ }^{\circ} \mathrm{C}$ for $1 \mathrm{~min}$, $55{ }^{\circ} \mathrm{C}$ for $2 \mathrm{~min}$ and $72{ }^{\circ} \mathrm{C}$ for $1 \mathrm{~min}$, with a final extension step of $72{ }^{\circ} \mathrm{C}$ for $10 \mathrm{~min}$. The amplicons were subjected to electrophoresis on agarose gel and stained with ethidium bromide. Amplification products of 201, 647 and 547 bp were obtained for genotypes A, B and $\mathrm{C}$, respectively.

Sequencing and phylogenetic analysis. The first-round PCR products of selected strains were subjected to nucleotide sequencing. Briefly, amplicons were excised from the gel and purified with gelextraction kits (Qiagen). The amplicons were subjected to direct sequencing using BigDye Terminator Cycle chemistry and a 3730 DNA analyser (Applied Biosystems). Raw sequence data were edited using BioEdit version 2.1 (Hall, 1999) and adjusted manually where needed. Phylogenetic analysis was carried out using MEGA4 (Tamura et al., 2007) using the $p$-distance algorithm and the neighbour-joining method.

\section{RESULTS}

\section{Assay format}

The assay was designed to facilitate identification of the three major NSP4 genotypes, A-C; these genotypes are shared across most mammalian rotavirus strains (Estes \& Kapikian, 2006). The genotyping method that we evaluated is based on a two-round PCR assay. In the first round, PCR consensus primers specific for highly conservative regions of the NSP4 gene were utilized. In the second round, the negative-sense consensus oligonucleotide primer from the first-round PCR and an equimolar mixture of three genotype-specific primers, targeting various regions of the NSP4 gene, were utilized. The genotype-specific 
Table 1. General characteristics and origin of the fully characterized strains used in the study and their NSP4 genotype

\begin{tabular}{|c|c|c|c|c|c|c|c|c|}
\hline \multirow[t]{2}{*}{ Strain } & \multirow{2}{*}{$\begin{array}{l}\text { No. of strains } \\
\text { with indicated } \\
\text { combination* }\end{array}$} & \multirow{2}{*}{$\begin{array}{c}\text { Species/strain } \\
\text { name } \dagger\end{array}$} & \multirow{2}{*}{$\begin{array}{c}\text { Country of } \\
\text { origin } \ddagger\end{array}$} & \multicolumn{4}{|c|}{ Type specificities } & \multirow[t]{2}{*}{ NSP4 } \\
\hline & & & & VP7 & VP4 & VP6 & E-type $\$$ & \\
\hline \multirow[t]{9}{*}{ Reference strains } & $\mathrm{NA}$ & $\mathrm{Hu} / \mathrm{WA}$ & & G1 & $\mathrm{P}[8]$ & SGII & $\mathrm{L}$ & B \\
\hline & $\mathrm{NA}$ & $\mathrm{Hu} / \mathrm{DS} 1$ & & G2 & $\mathrm{P}[4]$ & SGI & $\mathrm{S}$ & A \\
\hline & $\mathrm{NA}$ & $\mathrm{Hu} / \mathrm{P}$ & & G3 & $\mathrm{P}[8]$ & SGII & $\mathrm{L}$ & $\mathrm{B}$ \\
\hline & NA & $\mathrm{Hu} / 69 \mathrm{M}$ & & G8 & $\mathrm{P}[10]$ & SGII & SS & A \\
\hline & NA & Hu/HAL1166 & & G8 & $\mathrm{P}[14]$ & SGII & $\mathrm{L}$ & A \\
\hline & $\mathrm{NA}$ & $\mathrm{Hu} / \mathrm{WI} 61$ & & G9 & $\mathrm{P}[8]$ & SGII & $\mathrm{L}$ & $\mathrm{B}$ \\
\hline & $\mathrm{NA}$ & $\mathrm{Hu} / 116 \mathrm{E}$ & & G9 & $\mathrm{P}[11]$ & SGII & $\mathrm{L}$ & $\mathrm{B}$ \\
\hline & $\mathrm{NA}$ & $\mathrm{Hu} / \mathrm{PA} 169$ & & G6 & $\mathrm{P}[14]$ & SGI & $\mathrm{L}$ & $\mathrm{A}$ \\
\hline & $\mathrm{NA}$ & $\mathrm{Hu} / \mathrm{PA} 151$ & & G6 & $\mathrm{P}[9]$ & SGI & $\mathrm{L}$ & $\mathrm{A}$ \\
\hline \multirow[t]{23}{*}{ Field strains } & 3 & $\mathrm{Hu}$ & ITA-1 & G1 & $\mathrm{P}[8]$ & SGII & $\mathrm{L}$ & $\mathrm{B}$ \\
\hline & 3 & $\mathrm{Hu}$ & ITA-1 & G1 & $\mathrm{P}[8]$ & SGII & $S$ & $\mathrm{~B}$ \\
\hline & 1 & $\mathrm{Hu}$ & ITA-1 & G1 & $\mathrm{P}[8]$ & SGI & $\mathrm{L}$ & $\mathrm{B}$ \\
\hline & 2 & $\mathrm{Hu}$ & ITA-1 & $\mathrm{G} 1+2$ & $\mathrm{P}[4]$ & SGI & $S$ & A \\
\hline & 1 & $\mathrm{Hu}$ & ITA-1 & G2 & $\mathrm{P}[4]$ & SGI & $S$ & A \\
\hline & 3 & $\mathrm{Hu}$ & ITA-1 & G6 & $\mathrm{P}[14]$ & SGI & $\mathrm{L}$ & A \\
\hline & 2 & $\mathrm{Hu}$ & ITA-1 & G6 & $\mathrm{P}[9]$ & SGI & $\mathrm{L}$ & A \\
\hline & 2 & Po & ITA-1 & G5 & $\mathrm{P}[7]$ & GGI & $\mathrm{L}$ & B \\
\hline & 1 & Po & ITA-1 & G2 & $\mathrm{P}[23]$ & GGI & $\mathrm{L}$ & B \\
\hline & 2 & Po & ITA-1 & G3 & $\mathrm{P}[6]$ & GGI & $\mathrm{L}$ & B \\
\hline & 1 & $\mathrm{Hu}$ & ITA-2 & G3 & $\mathrm{P}[3]$ & SGI & $\mathrm{L}$ & $\mathrm{C}$ \\
\hline & 2 & $\mathrm{Hu}$ & IND & G1 & $\mathrm{P}[8]$ & GGII & $\mathrm{L}$ & B \\
\hline & 2 & $\mathrm{Hu}$ & IND & G1 & $\mathrm{P}[4]$ & GGII & $\mathrm{L}$ & B \\
\hline & 2 & $\mathrm{Hu}$ & IND & G2 & $\mathrm{P}[4]$ & GGI & $S$ & A \\
\hline & 2 & $\mathrm{Hu}$ & IND & G9 & $\mathrm{P}[8]$ & GGII & $\mathrm{L}$ & B \\
\hline & 2 & $\mathrm{Hu}$ & IND & G10 & $\mathrm{P}[11]$ & GGI & $\mathrm{L}$ & A \\
\hline & 2 & $\mathrm{Hu}$ & IND & G12 & $\mathrm{P}[6]$ & GGII & $\mathrm{L}$ & B \\
\hline & 1 & $\mathrm{Hu}$ & IND & G12 & $\mathrm{P}[8]$ & GGII & $\mathrm{L}$ & B \\
\hline & 2 & $\mathrm{Hu}$ & HUN & G6 & $\mathrm{P}[9]$ & SGI & $\mathrm{L}$ & A \\
\hline & 2 & $\mathrm{Hu}$ & HUN & G6 & $\mathrm{P}[9]$ & SGI & $\mathrm{L}$ & $\mathrm{C}$ \\
\hline & 1 & $\mathrm{Hu}$ & HUN & G6 & $\mathrm{P}[14]$ & SGI & $\mathrm{L}$ & A \\
\hline & 2 & $\mathrm{Hu}$ & HUN & G4 & $\mathrm{P}[6]$ & GGI & $\mathrm{L}$ & B \\
\hline & 1 & $\mathrm{Hu}$ & HUN & G3 & $\mathrm{P}[9]$ & SGI & $\mathrm{L}$ & A \\
\hline
\end{tabular}

${ }^{*} \mathrm{NA}$, Not applicable.

$\dagger$ Bo, bovine; $\mathrm{Ca}$, canine; Fe, feline; $\mathrm{Hu}$, human; Po, porcine; Si, simian. $\ddagger$ IND, India; ITA-1, Bari; ITA-2, Palermo; HUN, Hungary.

$\$$ L, Long; S, short; SS, supershort. 


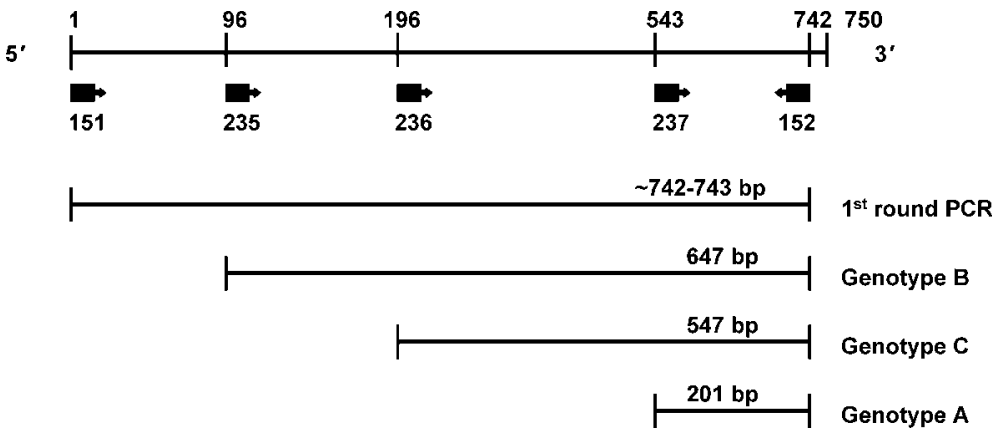

Fig. 1. Location of PCR primers on the NSP4 gene and expected lengths of amplified segments. Numbers above and below lines indicate relevant nucleotide positions within the NSP4 gene. The expected amplicon sizes of the first-round PCR product and the genotype-specific products are indicated.

reaction was evaluated from the differences in amplicon size following agarose gel electrophoresis (Figs 2 and 3 ).

\section{NSP4 typing of human and animal rotaviruses using hemi-nested PCR}

The four collaborating laboratories tested a total of 182 locally circulating human rotavirus strains and 10 laboratory reference strains (Table 1). These 192 human strains represented common combinations with global distribution (i.e. G1P[8], G2P[4], G3P[8], G4P[8] and G9P[8]), some newly emerging strains (i.e. G12P[6] and G12P[8]) and several unusual combinations, such as the rare reassortants of common G and P types (e.g. G1P[4]) and either locally or globally dispersed epidemiologically minor strains of possible animal origin (G3P[3], G3P[9], G4P[6], G6P[9], G6P[14], G8P[10], G8P[14], G9P[11] and G10P[11]). A novel antigen combination, G6P[4], identified in Palermo, Sicily, was also successfully NSP4-genotyped. The majority of human strains were collected from children with diarrhoea; however, a number of the

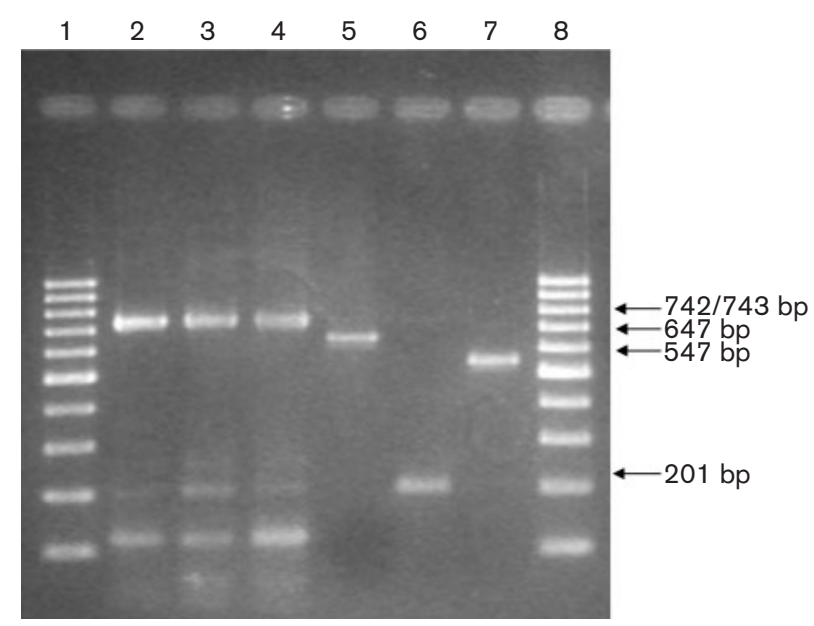

Fig. 2. Agarose gel electrophoresis of first-round (lanes 2-4) and second-round (lanes 5-7) PCR products. Lanes: 1 and 8, $100 \mathrm{bp}$ ladder; 2 and 5 , genotype $B$ strain (WA); 3 and 6 , genotype A strain (DS1); 4 and 7, genotype C strain (K9).
Indian strains $(\mathrm{G} 10 \mathrm{P}[11])$ and some reference strains (e.g. ST3, G4P[6]; 116E, G9P[11]) were collected from asymptomatic cases (Tables 1 and 2).

As a variety of animal strains were also included in the primer design, it was expected that the primers would work with animal strains sharing NSP4 genotype specificity with

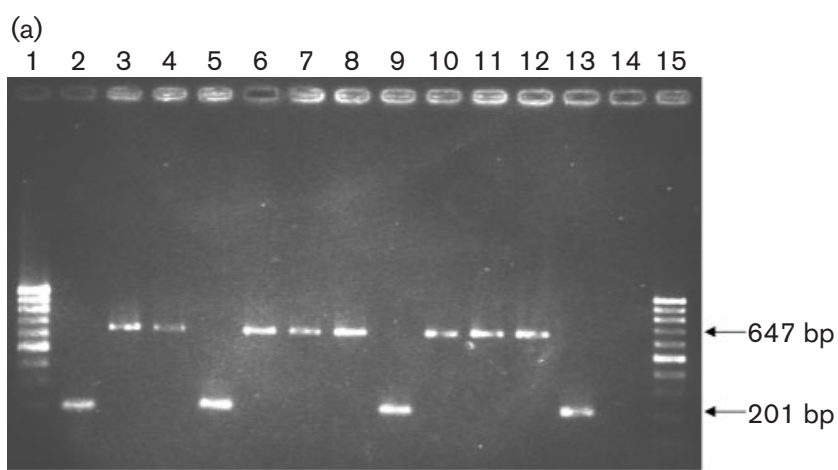

(b)

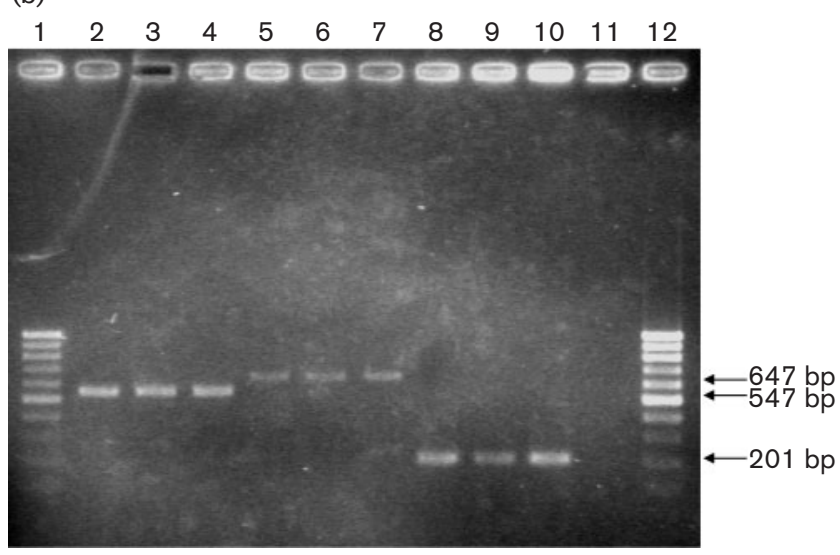

Fig. 3. Agarose gel electrophoresis of second-round PCR products demonstrating the efficiency with selected human field, animal field and laboratory strains. (a) Lanes: 1 and 15, $100 \mathrm{bp}$ ladder; 2, 5, 9 and 13, genotype A human strains; 3, 4, 6-8, 1012, genotype B human strains; 14, negative control. (b) Lanes: 1 and 12, 100 bp ladder; 2-4, genotype C canine strains; 5-7, genotype $B$ porcine strains; 8-10, genotype A bovine (NCDV), feline and simian strains (SA11), respectively; 11, negative control. 
Table 2. General characteristics and origin of the partially characterized strains used in the study and their NSP4 genotype See Table 1 for abbreviations. -, Data not available.

\begin{tabular}{|c|c|c|c|c|c|c|c|}
\hline \multirow{2}{*}{$\begin{array}{l}\text { No. of strains with the } \\
\text { indicated combination }\end{array}$} & \multirow{2}{*}{$\begin{array}{l}\text { Species/strain } \\
\text { name }\end{array}$} & \multirow{2}{*}{$\begin{array}{l}\text { Country of } \\
\text { origin }\end{array}$} & \multicolumn{4}{|c|}{ Type specificities } & \multirow[t]{2}{*}{ NSP4 } \\
\hline & & & VP7 & VP4 & VP6 & E-type & \\
\hline 2 & $\mathrm{Hu}$ & ITA-1 & $\mathrm{G} 2$ & $\mathrm{P}[4]$ & SGI & - & A \\
\hline 2 & $\mathrm{Hu}$ & ITA-1 & G3 & $\mathrm{P}[8]$ & SGII & - & $\mathrm{B}$ \\
\hline 3 & $\mathrm{Hu}$ & ITA-1 & $\mathrm{G} 1+2$ & $\mathrm{P}[8]$ & SGII & - & $\mathrm{B}$ \\
\hline 1 & $\mathrm{Hu}$ & ITA-1 & $\mathrm{G} 1+2+3$ & $\mathrm{P}[4]$ & SGI & - & A \\
\hline 3 & Po & ITA-1 & G9 & - & GGI & $\mathrm{L}$ & $\mathrm{B}$ \\
\hline 1 & Po & ITA-1 & G9 & $\mathrm{P}[7]$ & - & - & $\mathrm{B}$ \\
\hline 1 & Po & ITA-1 & G9 & $\mathrm{P}[6]$ & GGI & - & $\mathrm{B}$ \\
\hline 1 & Po & ITA-1 & $\mathrm{G} 4+9$ & $\mathrm{P}[6]$ & GGI & - & $\mathrm{B}$ \\
\hline 2 & Po & ITA-1 & G5 & $\mathrm{P}[6]$ & GGI & - & $\mathrm{B}$ \\
\hline 2 & Po & ITA-1 & G2 & - & - & - & $\mathrm{B}$ \\
\hline 1 & Po & ITA-1 & G3 & $\mathrm{P}[6]$ & GGI & - & $\mathrm{B}$ \\
\hline 1 & Po & ITA-1 & - & $\mathrm{P}[6]$ & GGI & $\mathrm{L}$ & B \\
\hline 1 & Po & ITA-1 & - & $\mathrm{P}[6]$ & GGI & - & B \\
\hline 2 & Po & ITA-1 & G4 & $\mathrm{P}[6]$ & GGI & - & B \\
\hline 1 & $\mathrm{Fe}$ & ITA-1 & G3 & $\mathrm{P}[9]$ & GGI & - & $\mathrm{A}$ \\
\hline 1 & $\mathrm{Ca}$ & ITA-1 & G3 & $\mathrm{P}[3]$ & - & - & $\mathrm{C}$ \\
\hline 2 & $\mathrm{Ca}$ & ITA-1 & G3 & - & - & - & $\mathrm{C}$ \\
\hline 1 & $\mathrm{Hu}$ & ITA-2 & G6 & $\mathrm{P}[4]$ & SGI & - & A \\
\hline 1 & $\mathrm{Hu}$ & ITA-2 & G1 & $\mathrm{P}[8]$ & - & $\mathrm{L}$ & B \\
\hline 1 & $\mathrm{Hu}$ & ITA-2 & G6 & $\mathrm{P}[9]$ & SGI & - & A \\
\hline 1 & $\mathrm{Hu}$ & IND & G1 & - & - & - & B \\
\hline 3 & $\mathrm{Hu}$ & IND & G1 & $\mathrm{P}[4]$ & - & - & B \\
\hline 8 & $\mathrm{Hu}$ & IND & G9 & $\mathrm{P}[8]$ & - & - & B \\
\hline 1 & $\mathrm{Hu}$ & IND & G9 & $\mathrm{P}[8]+[4]$ & - & - & B \\
\hline 1 & $\mathrm{Hu}$ & IND & G9 & $\mathrm{P}[8]+[4]$ & - & - & $A+B$ \\
\hline 6 & $\mathrm{Hu}$ & IND & G10 & $\mathrm{P}[11]$ & - & - & $\mathrm{A}$ \\
\hline 1 & $\mathrm{Hu}$ & IND & G12 & $\mathrm{P}[6]$ & - & - & B \\
\hline 21 & $\mathrm{Hu}$ & HUN & G1 & $\mathrm{P}[8]$ & - & $\mathrm{L}$ & B \\
\hline 5 & $\mathrm{Hu}$ & HUN & G2 & $\mathrm{P}[4]$ & - & $S$ & A \\
\hline 3 & $\mathrm{Hu}$ & HUN & G3 & $\mathrm{P}[8]$ & - & $\mathrm{L}$ & B \\
\hline 12 & $\mathrm{Hu}$ & HUN & G4 & $\mathrm{P}[8]$ & - & $\mathrm{L}$ & B \\
\hline 3 & $\mathrm{Hu}$ & HUN & G4 & $\mathrm{P}[6]$ & - & $\mathrm{L}$ & B \\
\hline 10 & $\mathrm{Hu}$ & HUN & G9 & $\mathrm{P}[8]$ & - & $\mathrm{L}$ & B \\
\hline 3 & $\mathrm{Hu}$ & HUN & G1 & - & - & $\mathrm{L}$ & B \\
\hline 2 & $\mathrm{Hu}$ & HUN & G2 & - & - & $\mathrm{S}$ & A \\
\hline 4 & $\mathrm{Hu}$ & HUN & G4 & - & - & $\mathrm{L}$ & B \\
\hline 1 & $\mathrm{Hu}$ & HUN & G9 & - & - & $\mathrm{L}$ & B \\
\hline 1 & $\mathrm{Hu}$ & HUN & - & $\mathrm{P}[8]$ & - & $\mathrm{L}$ & B \\
\hline
\end{tabular}


that of human strains. Altogether, 35 animal strains, including the reference laboratory strains SA11 (simian, G3P[2]), NCDV (bovine, G6P[1]), K9 and CU-1 (canine, $\mathrm{G} 3 \mathrm{P}[3]$ ), together with 31 field isolates detected in Italy between 2003 and 2006 of various host origins (e.g. canine, $\mathrm{G} 3 \mathrm{P}[3]$; feline, G3P[9]; porcine, G2-like $\mathrm{P}[23]$, G3P[6], G4P[6], G5P[6], G5P[7], G5P[26], G5P[27], G9P[6] and the rare G9P[7] strain) were NSP4-genotyped in the assay (Tables 1 and 2).

Tables 1 and 2 show an overall description of the characteristics of the strains, including the $G$ and $P$ type, VP6 subgroup or genogroup, E-type and NSP4 genotype. These tables helped us to search for the genetic linkage between the NSP4 and VP6 genes (Iturriza-Gómara et al., 2003 ) in strains of various host origins. In general, the vast majority of human strains (183/192) had the conservative configurations of NSP4 and VP6 genes, and only a minority of human strains (6/192) included unusual configurations, such as genotype A NSP4 in linkage with SGII VP6 (e.g. HAL1166 and 69M) or genotype B NSP4 in linkage with GGI or SGI VP6 (e.g. two Italian strains with either $\mathrm{G} 1 \mathrm{P}[8]$ or $\mathrm{G} 3 \mathrm{P}[8]$ specificity, and two Hungarian G4P[6] strains). In addition, three human strains with a genotype C NSP4 gene (two G6P[9] strains and a single G3P[3] strain) carried the GGI or SGI VP6 gene.
With regard to the animal strains, limited amounts of data were derived from bovine, simian and canine strains; all had a genotype A or C NSP4 gene combined with an SGI VP6 gene. A single feline G3P[9] strain had a genotype A NSP4 gene in combination with a GGI VP6 gene. The 25 porcine strains that were characterized in this study carried a genotype B NSP4 gene in linkage with a GGI VP6 gene.

\section{Confirmation of test results by sequencing}

A total of 37 strains were subjected to sequencing in order to confirm the results of the NSP4 PCR genotyping. Phylogenetic analysis confirmed the results obtained by RT-PCR-based genotyping (Fig. 4).

\section{DISCUSSION}

NSP4 is a key protein involved in the morphogenesis and pathogenesis of rotaviruses. NSP4 acts as an intracellular receptor for single-shelled particles and mediates virus assembly into double-shelled particles. NSP4 alone is able to induce diarrhoea in experimental animals through a $\mathrm{Ca}^{2+}$-dependent signalling pathway. The enterotoxigenic domain of NSP4 contains a 22 aa sequence (aa 114-135) that mimics some features of the full-length protein.

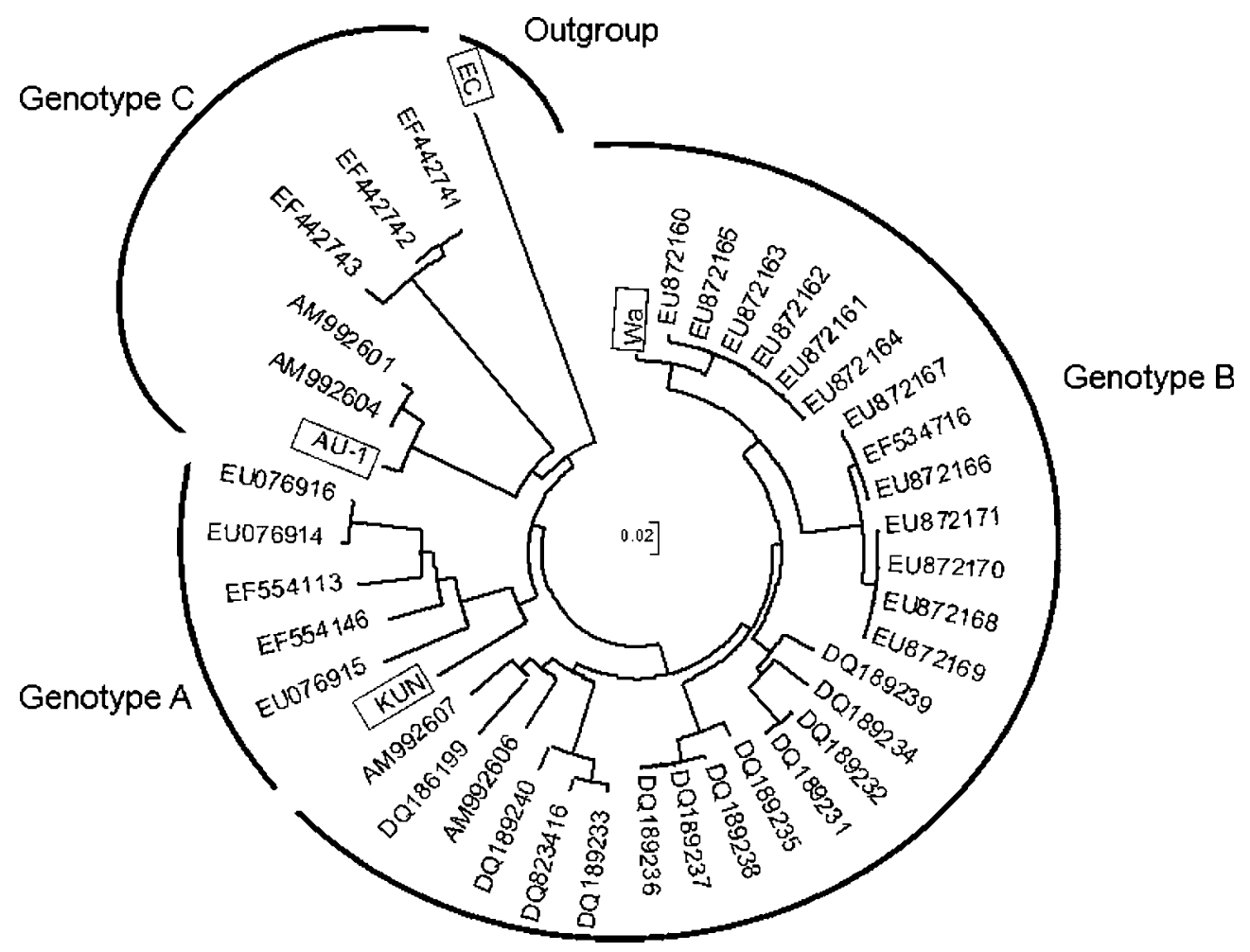

Fig. 4. Phylogenetic tree based on nucleotide sequences (nt 55-520, strain WA) of human and animal rotavirus strains genotyped and characterized in this study. Reference strains are boxed and study strains are indicated by their GenBank accession numbers. Bar, 0.02 substitutions per nucleotide. 
Antibodies against NSP4, or against the toxic peptide, are able to prevent watery diarrhoea, although the precise in vivo mechanisms of protection are unknown (Ball et al., 2005; Estes \& Kapikian, 2006). These findings prompted investigations to explore the therapeutic and preventive potential of NSP4 and anti-NSP4 antibodies. Thus, in addition to the outer capsid components VP7 and VP4, and the inner-capsid protein VP6, the enterotoxin NSP4 is currently a focus of vaccine development (Yu \& Langridge, 2001; Choi et al., 2006).

Thus the NSP4 gene is now considered to be as important as the inner and outer capsid genes. We felt that a rapid and reliable genotyping system for NSP4 similar to the broadly utilized nested PCR-based genotyping assays developed for the VP4 and VP7 genes would be beneficial for epidemiological investigations. Therefore, we developed and evaluated a triplex hemi-nested PCR assay that targets the three main genotypes of the rotavirus NSP4 gene. Our assay was highly specific. It should be noted, however, that non-specific products were obtained when the assay was performed as a single-round PCR after generating cDNA with random hexamer oligonucleotides (results not shown). We did not investigate the assay's sensitivity, as our original intention was for the NSP4 genotyping system to support the $G$ and $P$ type data collected in most laboratories involved in rotavirus surveillance activity. Thus only those specimens where the amount of template RNA was previously found to be sufficient for $G$ and $P$ genotyping assays were considered for NSP4 genotyping in our strain typing algorithm. To confirm the specificity of the primers, full-length or almost full-length NSP4 gene sequences were determined for selected rotavirus strains. Sequence data for these strains were in agreement with the RT-PCR-based genotyping data, validating our assay.

Other protocols are available for prediction of the NSP4 genotype. The NSP4 genotyping assay designed by Ray et al. (2003) identified nine genotype A strains and 18 genotype B strains among 27 human Indian rotaviruses. However, in that study, the primers were designed using the sequence of a few prototype viruses. Another NSP4 genotyping assay was published after we had completed our study (Rodríguez-Díaz et al., 2008). Taking into account the genetic variability of human rotaviruses, those authors designed a set of consensus primers. They validated the assay using seven reference strains and properly characterized a Swedish collection of 77 human strains, all of which were characterized as genotype B. In our study, the primer sets were designed using a similar strategy, using a selection of 75 sequences of human and animal strains of the three major mammalian NSP4 genotypes $(\mathrm{A}-\mathrm{C})$. In order to compensate for the genetic variability in the NSP4 gene, degenerate bases were introduced into the oligonucleotides. The reliability of this new NSP4 genotyping assay was assessed using a large sample set that included 14 reference strains and 182 human and 31 animal field strains from diverse geographical settings and encompassing several G/P combinations.
Recently, genetic linkage has been observed between the NSP4 gene and the VP6 gene that seems to correlate with the host species origin (Iturriza-Gomara et al., 2003). Molecular analysis of the human strains revealed that the genotype A NSP4 gene segregates with the SGI/GGI VP6 gene, whereas genotype B NSP4 is in linkage with the SGII/ GGII VP6 specificity. Data for the genotype C NSP4 gene are scarce; all of these strains have thus far been identified only in linkage with SGI/GGI VP6 specificity. In this study, the proposed genetic linkages were seen in the majority of strains. Only five human strains were demonstrated to have an inverse genetic combination between the NSP4 and VP6 specificities. The relative rarity of such human strains might be explained by genetic/phenotypic instability between non-compatible alleles of the NSP4 and VP6 genes. It is not currently known how the VP6 and NSP4 genes segregate in animal rotaviruses. Ciarlet et al. (2000) pointed out that NSP4 genotype A does not correlate with the subgroup specificity, although they did not exclude the possibility of a correlation between subgroup specificity and NSP4 type in genotypes B, C and D. A more recent study reported a lack of linkage in a porcine-bovine reassortant strain detected in pig (Ghosh et al., 2007). Moreover, our analysis suggests that NSP4 genotype B segregates with the GGI VP6 gene in the majority of Italian porcine rotavirus strains, representing a genetic linkage considered rare in human strains. The conceptual basis of the genetic linkage between various specificities of NSP4 and VP6 genes has been related to the maturation step of the virus life cycle, when NSP4 anchored in the endoplasmic reticulum serves as a receptor for VP6-coated single-shelled particles (Iturriza-Gomara et al., 2003). It seemed plausible to assume that, in this molecular process, NSP4 of a certain genotype specificity may favourably bind to VP6 of a particular specificity. However, the frequent detection of an unexpected linkage in porcine rotaviruses raises questions concerning the driving forces and selection mechanisms during the long-term evolution of rotaviruses in various host species that, for example, has led to a different pattern of genetic linkage between NSP4 and VP6 genes in human strains from that seen in a number of recently investigated porcine strains.

Four human G3P[9] strains and one feline G3P[9] strain were found to possess an NSP4 A genotype, instead of NSP4 C. By sequence analysis, the Italian G3P[9] human strains were found to be related to strains of either human or feline origin in the VP7, VP4 and VP6 genes, whilst in the NSP4 gene, the viruses resembled G2P[4] human strains, suggesting a reassortment event between heterologous strains (De Grazia et al., 2008).

In conclusion, since the early 1990s, various multiplex genotyping assays have been developed for the outer capsid genes of rotaviruses, and this approach is used routinely in most laboratories involved in strain surveillance. A recent increase in the number of available NSP4 gene sequences in public databases has allowed the development of similar typing assays to identify and distinguish NSP4 genotypes 
(Ray et al., 2003; Rodríguez-Díaz et al., 2008; this study). Routine NSP4 genotyping may help to determine the gene configurations of unusual rotaviruses and identify interspecies transmission of heterologous strains. However, because various genotype specificities (including G, P or NSP4 types) potentially detectable by standard genotyping PCR assays are shared in different host species, a suspect zoonotic event or reassortment between heterologous strains requires confirmation by sequencing and phylogenetic analysis. As the NSP4 gene is an important virulence factor, and genotype-specific differences may occur in its activity, understanding genotype distributions and further analysis of their genetic linkages with other rotavirus genes may provide a more penetrating insight into the epidemiology and ecology of both the predominant and the epidemiologically minor rotavirus strains.

\section{ACKNOWLEDGEMENTS}

The study was supported by the Hungarian Research Fund (OTKA, T049020) and the European Union (EVENT program, SP22-CT2004-502571). K. B. is a recipient of the Bolyai Janos Scholarship awarded by the Hungarian Academy of Sciences. The technical assistance of Gertrud Domonkos and Elonora Lorusso is highly appreciated. We thank Jon Gentsch for sharing some reference human rotavirus strains with us. We are also grateful to James Craik for critical reading and editing of the manuscript.

\section{REFERENCES}

Ball, J. M., Mitchell, D. M., Gibbons, T. F. \& Parr, R. D. (2005). Rotavirus NSP4: a multifunctional viral enterotoxin. Viral Immunol 18, 27-40.

Bányai, K., Gentsch, J. R., Griffin, D. D., Holmes, J. L., Glass, R. I. \& Szücs, G. (2003). Genetic variability among serotype G6 human rotaviruses: identification of a novel lineage isolated in Hungary. $J$ Med Virol 71, 124-134.

Boom, R., Sol, C. J., Salimans, M. M., Jansen, C. L., Wertheim-van Dillen, P. M. \& van der Noordaa, J. (1990). Rapid and simple method for purification of nucleic acids. J Clin Microbiol 28, 495-503.

Chang, K. O., Parwani, A. V. \& Saif, L. J. (1996). The characterization of VP7 ( $\mathrm{G}$ type) and VP4 (P type) genes of bovine group A rotaviruses from field samples using RT-PCR and RFLP analysis. Arch Virol 141, 1727-1739.

Choi, N. W., Estes, M. K. \& Langridge, W. H. (2006). Mucosal immunization with a ricin toxin B subunit-rotavirus NSP4 fusion protein stimulates a Th1 lymphocyte response. J Biotechnol 121, 272283.

Ciarlet, M., Liprandi, F., Conner, M. E. \& Estes, M. K. (2000). Species specificity and interspecies relatedness of NSP4 genetic groups by comparative NSP4 sequence analyses of animal rotaviruses. Arch Virol 145, 371-383.

Das, B. K., Gentsch, J. R., Cicirello, H. G., Woods, P. A., Gupta, A., Ramachandran, M., Kumar, R., Bhan, M. K. \& Glass, R. I. (1994). Characterization of rotavirus strains from newborns in New Delhi, India. J Clin Microbiol 32, 1820-1822.

De Grazia, S., Giammanco, G. M., Martella, V., Ramirez, S., Colomba, C., Cascio, A. \& Arista, S. (2008). Rare AU-1-like G3P[9] human rotaviruses with a Kun-like NSP4 gene detected in children with diarrhea in Italy. J Clin Microbiol 46, 357-360.
DiStefano, D. J., Kraiouchkine, N., Mallette, L., Maliga, M., Kulnis, G., Keller, P. M., Clark, H. F. \& Shaw, A. R. (2005). Novel rotavirus VP7 typing assay using a one-step reverse transcriptase PCR protocol and product sequencing and utility of the assay for epidemiological studies and strain characterization, including serotype subgroup analysis. J Clin Microbiol 43, 5876-5880.

Dolan, K. T., Twist, E. M., Horton-Slight, P., Forrer, C., Bell, L. M., Jr, Plotkin, S. A. \& Clark, H. F. (1985). Epidemiology of rotavirus electropherotypes determined by a simplified diagnostic technique with RNA analysis. J Clin Microbiol 21, 753-758.

Dubois, E., Le Guyader, F., Haugarreau, L., Kopecka, H., Cormier, M. \& Pommepuy, M. (1997). Molecular epidemiological survey of rotaviruses in sewage by reverse transcriptase seminested PCR and restriction fragment length polymorphism assay. Appl Environ Microbiol 63, 1794-1800.

Estes, M. K. \& Kapikian, A. Z. (2006). Rotaviruses. In Fields Virology, 5th edn, vol. 2, pp. 1917-1974. Edited by D. M. Knipe, P. M. Howley, D. E. Griffin, R. A. Lamb, M. A. Martin, B. Roizman \& S. E. Straus. Philadelphia: Lippincott Williams \& Wilkins/Wolters Kluwer.

Gentsch, J. R., Glass, R. I., Woods, P., Gouvea, V., Gorziglia, M., Flores, J., Das, B. K. \& Bhan, M. K. (1992). Identification of group A rotavirus gene 4 types by polymerase chain reaction. J Clin Microbiol 30, 1365-1373.

Ghosh, S., Varghese, V., Samajdar, S., Bhattacharya, S. K., Kobayashi, N. \& Naik, T. N. (2007). Evidence for independent segregation of the VP6- and NSP4-encoding genes in porcine group A rotavirus G6P[13] strains. Arch Virol 152, 423-429.

Gouvea, V., Glass, R. I., Woods, P., Taniguchi, K., Clark, H. F., Forrester, B. \& Fang, Z. Y. (1990). Polymerase chain reaction amplification and typing of rotavirus nucleic acid from stool specimens. J Clin Microbiol 28, 276-282.

Gouvea, V., Ramirez, C., Li, B., Santos, N., Saif, L., Clark, H. F. \& Hoshino, Y. (1993). Restriction endonuclease analysis of the VP7 genes of human and animal rotaviruses. J Clin Microbiol 31, 917-923.

Gouvea, V., Santos, N. \& Timenetsky, M. C. (1994a). Identification of bovine and porcine rotavirus G types by PCR. J Clin Microbiol 32, 1338-1340.

Gouvea, V., Santos, N. \& Timenetsky, M. C. (1994b). VP4 typing of bovine and porcine group A rotaviruses by PCR. J Clin Microbiol 32, 1333-1337.

Greenberg, H., McAuliffe, V., Valdesuso, J., Wyatt, R., Flores, J., Kalica, A., Hoshino, Y. \& Singh, N. (1983). Serological analysis of the subgroup protein of rotavirus using monoclonal antibodies. Infect Immun 39, 91-99.

Hall, T. A. (1999). BioEdit: a user-friendly biological sequence alignment editor and analysis program for Windows 95/98/NT. Nucleic Acids Symp Ser 41, 95-98.

Hussein, H. A., Frost, E. H., Deslandes, S., Talbot, B. \& Elazhary, Y. (1997). Restriction endonucleases whose sites are predictable from the amino acid sequence offer an improved strategy for typing bovine rotaviruses. Mol Cell Probes 11, 355-361.

lizuka, M., Chiba, M., Masamune, O., Gerna, G. \& Nakagomi, O. (1993). Molecular characterization of human rotavirus VP4 genes by polymerase chain reaction and restriction fragment length polymorphism assay. Microbiol Immunol 37, 729-735.

Iturriza-Gómara, M., Wong, C., Blome, S., Desselberger, U. \& Gray, J. (2002). Molecular characterization of VP6 genes of human rotavirus isolates: correlation of genogroups with subgroups and evidence of independent segregation. J Virol 76, 6596-6601.

Iturriza-Gómara, M., Anderton, E., Kang, G., Gallimore, C., Phillips, W., Desselberger, U. \& Gray, J. (2003). Evidence for genetic linkage between the gene segments encoding NSP4 and VP6 proteins 
in common and reassortant human rotavirus strains. J Clin Microbiol 41, 3566-3573.

Iturriza-Gómara, M., Kang, G. \& Gray, J. (2004). Rotavirus genotyping: keeping up with an evolving population of human rotaviruses. J Clin Virol 31, 259-265.

Khamrin, P., Maneekarn, N., Peerakome, S., Chan-it, W., Yagyu, F., Okitsu, S. \& Ushijima, H. (2007). Novel porcine rotavirus of genotype $\mathrm{P}[27]$ shares new phylogenetic lineage with G2 porcine rotavirus strain. Virology 361, 243-252.

Kudo, S., Zhou, Y., Cao, X. R., Yamanishi, S., Nakata, S. \& Ushijima, H. (2001). Molecular characterization in the VP7, VP4 and NSP4 genes of human rotavirus serotype 4 (G4) isolated in Japan and Kenya. Microbiol Immunol 45, 167-171.

Martella, V., Ciarlet, M., Bányai, K., Lorusso, E., Arista, S., Lavazza, A., Pezzotti, G., Decaro, N., Cavalli, A. \& other authors (2007). Identification of group A porcine rotavirus strains bearing a novel VP4 (P) genotype in Italian swine herds. J Clin Microbiol 45, 577-580.

O'Halloran, F., Lynch, M., Cryan, B. \& Fanning, S. (2002). Application of restriction fragment length polymorphism analysis of VP7- encoding genes: fine comparison of Irish and global rotavirus isolates. J Clin Microbiol 40, 524-531.

Ray, P., Malik, J., Singh, R. K., Bhatnagar, S., Bahl, R., Kumar, R. \& Bhan, M. K. (2003). Rotavirus nonstructural protein NSP4 induces heterotypic antibody responses during natural infection in children. $J$ Infect Dis 187, 1786-1793.

Rodríguez-Díaz, J., Rubilar-Abreu, E., Spitzner, M., Hedlund, K. O., Liprandi, F. \& Svensson, L. (2008). Design of a multiplex nested PCR for genotyping of the NSP4 from group A rotavirus. J Virol Methods 149, 240-245.

Steyer, A., Poljsak-Prijatelj, M., Barlic-Maganja, D., Jamnikar, U., Mijovski, J. Z. \& Marin, J. (2007). Molecular characterization of a new porcine rotavirus $\mathrm{P}$ genotype found in an asymptomatic pig in Slovenia. Virology 359, 275-282.

Tamura, K., Dudley, J., Nei, M. \& Kumar, S. (2007). MEGA4: Molecular Evolutionary Genetics Analysis (MEGA) software version 4.0. Mol Biol Evol 24, 1596-1599.

Yu, J. \& Langridge, W. H. (2001). A plant-based multicomponent vaccine protects mice from enteric diseases. Nat Biotechnol 19, 548-552. 